\title{
Efficacy of Entrepreneurial Skills Acquisition: A Study of Nigerian University Graduate Entrepreneurs in Kano and Lagos Metroplis
}

\author{
Onyeaghala Obioma H. ${ }^{1 *}$, Okorie Goodluck² \\ ${ }^{1,2}$ Department of Business Administration, Federal University Wukari, Nigeria
}

*Corresponding Author: Onyeaghala Obioma H., Department of Business Administration, Federal University Wukari, Nigeria

\begin{abstract}
This study seeks to empirically assess the efficacy of entrepreneurial skills acquired by Nigerian University graduates. The study adopted the survey design and employed the questionnaire as instrument for data collection. The target population of the study consists of all Nigerian university graduates who established and run their own enterprise for the past ten years. To save cost and time, the researchers judgmentally focused on two major geographical zones in Nigeria: North and South, represented by Kano and Lagos. The population of graduate entrepreneurs operating for the past ten years in Kano and Lagos metropolis was established as 266. This population formed the basis for calculating the sample size of this study. Validity of the research instrument was established and its reliability conducted and ascertained. Descriptively, tables and percentages were used to group the responses of respondents to the questions that were asked, whereas, the Spearman's Rank Correlation Coefficient ( $r$ ) aided by SPSS was used in testing the formulated hypotheses. Result of the findings shows that: there is significant strong positive relationship between entrepreneurial skills acquisition and the measured efficacy indices or indicators: identification of business opportunities, taking advantage of business opportunities in the environment and the tendency to take calculated risk in business ventures. This study concludes that entrepreneurial skills acquisition helps Nigerian university graduates to identify and utilize business opportunities in their environment. In addition, risk taking was identified to be strongly linked with entrepreneurial skills in business venture. Recommendations were made that the entrepreneurship programme organized by Universities in Nigeria should be repositioned to focus more on skills acquisition because it equips students for venture creation and self employment. Furthermore, measures should be put in place to ensure that policy framework relating to entrepreneurship programme is galvanized, properly implemented and sustained.
\end{abstract}

Keywords: Efficacy, Innovation-Oriented, Dynamic Innovation, Time Risk, Competition Risk

\section{INTRODUCTION}

The entrepreneurial age is here with us. This is the time when destinies are defined and directed by men and women who risk their resources (time, money and energy) in establishing and running their own businesses - a fit powered by entrepreneurial skills. Entrepreneurial skills development refers to the acquisition of knowledge on certain talents or ability which makes an individual industrious, creative, fully engaged in productive activities and as a member of the labor force. Entrepreneurship development has been viewed as a means of stimulating economic growth through the generation of greater employment opportunities, the development of technological and conservation of foreign exchange earnings of national governments (Sule, 1986). It has also been conceived as a programme of activities to stimulate the knowledge, skill, behavior and attitudes of individual and groups to assume the role of entrepreneurs (Owualah, 1999).

In economies characterized by constrained labor demand from the private sector and high rate of unemployment, entrepreneurship support interventions targeting students becomes promising policy options (Amaechi 2005). In line with this, the federal government of Nigeria has put in place several strategies and policy frameworks towards entrepreneurial development. The policy implementation saw the introduction of Entrepreneurship Development Programmes (EDP) in Nigeria (Owualah, 1999). For instance, all undergraduate students in Nigerian Universities are required to register and pass entrepreneurial courses before graduation. Participants in Nigeria's national directorate of employment (NDE) and similar programmes in the country are expected to undergo EDP training, just 
to mention but a few. These programmes usually include entrepreneurial training which ranges from the preparation of business plan with emphasis on finance, marketing, management and production, identification of new business opportunities, alternative suppliers and market, sources of finance, training people to think and act in an entrepreneurial way (Amaechi 2005). This is supplemented by practical creative skills training that help for job creation.

Effective job creation hinges on the strategic scanning of the environment for the purposes of identifying immediate needs of the society and set process in motion to attend to those needs. It is the process put in motion that opens up the opportunities for resourceful engagement of human effort. A business venture is said to be created when an individual with requisite skills sets up an enterprise on his own and operate it successfully. This is the cardinal objective of entrepreneurship training for university undergraduate students. It is expected that the training will help them to acquire requisite skills with which to identify business opportunities and utilize them to create their own jobs, as well as align their skills with private employers' needs.

\subsection{Problem Presentation}

In Anyadike, Emeh and Ukah (2012) words, job creation has emerged as the single most critical economic challenge facing the world today. In Nigeria for instance graduate unemployment seems to be increasing to high heavens. Perhaps the increasing demand for white collar jobs which outnumbers available job opportunities has created unexpected unemployment rate, especially among university graduates. The last recruitment exercise of Nigeria Immigration Service simply put, attests to the fact that there is high rate of unemployment among Nigerian University graduates. Consequently, the high rate of unemployment among Nigerian University graduates questions the efficacy of entrepreneurial skills development programme organized in Nigerian Universities. The Nigerian University curriculum makes provision for students to take courses in entrepreneurship before they graduate. This is with the intention to adequately prepare them for self-employment.

Observation has shown that most of the university graduates move from one city to the other in search of white colour jobs with the feeling that it is the responsibility of government to create job for them. Many continue the search and in the process remain unemployed for years. Still, others think that the entrepreneurial skills development programme they underwent in school is just to make up course requirements for graduation. To further buttress this point, Adeyemo, (2009) reported that two fundamental issues are involved when a new skill is to be acquired. The first according to him is the conditions which promote acquisition and the second is the change that will occur when the skill is acquired. It is pertinent to ask if entrepreneurial skills development programme actually provides the platform for university graduates in Nigeria to identify opportunities and capacity to transform opportunities into business. Why do these graduates dump the entrepreneurial skills acquired by them in search of white collar jobs?

Importantly, attempts have been made by most researchers to undertake studies on entrepreneurship but none has investigated the efficacy of entrepreneurial skills acquired by Nigerian University graduates in terms of the following indicators or indices: identification of business opportunities, taking advantage of business opportunities and taking calculated risk in business ventures. Thus, this study is a departure from what people have done in the past. It therefore seeks to fill this knowledge gap. It is in response to the above stated problems that provoked this study.

\subsection{Objective of the Study}

The general objective of this study with reference to the problem stated above is to assess the efficacy of entrepreneurial skills acquired by Nigerian University graduates. The specific objectives are:

- To determine if there is significant relationship between entrepreneurial skills acquisition and identification of business opportunities by Nigerian University graduates.

- To ascertain if there is significant relationship between entrepreneurial skills acquisition and the taking advantage of opportunities in business environment by Nigerian University graduates.

- To establish if there is significant relationship between entrepreneurial skills acquisition and tendency to take calculated risk in business ventures by Nigerian University graduates. 


\subsection{Research Questions}

The research questions for this study are:

- Is there significant relationship between entrepreneurial skills acquisition and identification of business opportunities by Nigerian University graduates?

- Is there significant relationship between entrepreneurial skills acquisition and the taking advantage of opportunities in business environment by Nigerian University graduates?

- Is there significant relationship between entrepreneurial skills acquisition and the tendency to take calculated risk in business ventures by Nigerian University graduates?

\subsection{Research Hypotheses}

In light of the above research questions, three (3) null hypotheses were formulated for the study. They are:

$\mathbf{H}_{\mathbf{O} 1}$ : There is no significant relationship between entrepreneurial skills acquisition and identification of business opportunities by Nigerian University graduates

$\mathbf{H}_{\mathbf{O} 2}$ : There is no significant relationship between entrepreneurial skills acquisition and the taking advantage of opportunities in business environment by Nigerian University graduates

Ho $_{3}$ : There is no significant relationship between entrepreneurial skills acquisition and the tendency to take calculated risk in business venture by Nigerian University graduates.

\subsection{Scope of the Study}

This study surveyed only self-employed Nigerian trained university graduates who established and run their own enterprises for the past ten years in Kano and Lagos metropolis. The indices (indicators) measured for the independent (stimulus or explanatory) variables are: identification and creation of business opportunities, tendency to take calculated risk. Entrepreneurial skills acquisition is the dependent (criterion variable).

\subsection{Significance of the Study}

Findings from this study will justify if entrepreneurial skills acquisition programme achieves the above set objectives. This study will therefore be significant to university under-graduates such that they will see the need to be devoted to entrepreneurial skills development courses taught them in school. This is because the entrepreneurial skills development programme is aimed at equipping them with requisite skills to create ventures and become self-employed after graduation.

The larger society will equally benefit from this study, for it is when the unemployed graduates who constitute majority of the youths are meaningfully engaged, that most social vices such as: terrorism, kidnapping, armed-robbery, political thuggery, and internet hacking just to mention but few, will be curbed. The multiplier effect of this is that, it is only when the society is peaceful that government can smoothly implement policies which bear on the lives of her citizens.

\section{CONCEPTUAL FRAMEWORK}

\subsection{Concept of Entrepreneurship}

There is no conventional way to convey the meaning of entrepreneurship because individuals have presented different definitions which reflects their points of views. Martins and Osberg (2007) view entrepreneurship as a combination of the ability to identify opportunities, personal competencies to use such opportunities and the capacity to transform opportunities into business. Esomonu (1998), defined entrepreneurship as the effective manipulation of human intelligence as demonstrated in a creative and innovative performance.

The National Directorate of Employment (1989) sees entrepreneurship as an art which involves recognizing a business opportunity, mobilizing resources and persisting to exploit that opportunity. Tijani (2004) defines entrepreneurship as the process of increasing the supply of entrepreneurs or adding to the stock of existing small medium and big enterprises available to a country by creating, innovating and promoting many capable entrepreneurs who can successfully run innovative 
enterprises, nurture them to grow and sustain them with a view to achieving broad socio-economic development goals.

Uru and Yozgat (2009); Baron and Henry (2010); Kuratko and Hodgetts (2004); Bagheri and Pihie, (2010) conceptualizes entrepreneurship as: innovation and creativity, new phenomenon, new methodologies and new technology, change and value creation in a dynamic process, opportunity seeking and transformation. To them, the entrepreneur represent as an actor, innovator or a developer of technology.

Schumpeter in Stevenson (2007), identified innovation as a critical dimension of economic change, he argued that economic change revolves around innovation and entrepreneurial activities. He sought to prove that innovation-oriented organizations or business could provide better results than noninnovation-oriented organization.

The concept of innovation and its corollary development embraces four (4) functions (Khanka 2002).

- The introduction of a new product with which consumers are not yet familiar with or introduction of a new quality of existing product.

- The introduction of new method of production not yet tested by experience in the branch of manufacturer concerned, a discovery scientifically new and a new way of handling a commodity commercially.

- Conquest of a new source of supply of raw material and

- The carrying out of the new organization or any industry.

Creativity is seen as the generation of novel, unique and original ideas that are related to the process and procedures used in the work place (Fills, 2012). Generally, creativity means the conceptualization of objects or ideas that did not previously exist. Bosiak, (2013) explains that creativity can be viewed as the mental process that helps generate ideas, i.e., it generates a lot of solutions to a specific problem.

\subsection{Entrepreneurial Skills}

Skills represent particular ways of using capacities in relation to environmental demands, with human being and external situation together forming a functional system (Adeyemo 2009). Entrepreneurial skills are skills that helps one establish and operate a venture successfully. These skills are acquired through entrepreneurial development programmes. Kilby (1971) opines that entrepreneurial skills encompasses the perception of economic opportunity, technical and organizational innovations, gaining commands over scarce resources, taking responsibilities for internal management and for external advancement of the firm in all aspects of enterprise. According to Adeyemo (2009), entrepreneurial skills are skills needed to succeed in business. They are basic skills necessary to enable one start, develop, finance and succeed in business enterprise.

Skills acquisition as further explained by Onyeaghala, Edema and Orji (2013) is a specific form of learning, which is the representation of information in memory concerning some environmental or cognitive event. Pleshetter, (2009) opines that the process of acquisition and development of entrepreneurial skill is concerned with four main stages and these are:

- To objectively analyze and identify the current and foreseeable skills needs to the business, in terms of management, administrative and technical skills and the relative importance of these.

- To identify the entrepreneur's own personal goal and objectives and accurately analyze and evaluate his or her own skills and resources in relation to these.

- To produce a realistic personal development plan for the potential entrepreneur.

- To monitor the on-going performance of the entrepreneur once the business has started and progress made towards developing the new skills that had been previously identified as necessary for the success of the business. This applies both to the entrepreneur's personal needs and to the process of assisting employees to develop new skills that will also benefit the business. 


\subsection{Characteristics of Entrepreneurial Personality}

To acquire an entrepreneurial skill, a hierarchy of behavioral units (traits) needs to be constructed. This idea was pointed out as far as 1897 by Bryan and Harter (Rae, 2007), when they demonstrated the successive levels of skill involved in telegraphy.

Ottih (2000) lists and explains these behavioral traits that characterize entrepreneurial personality as: creativity, independence, leadership and risk taking.

Creativity: Entrepreneurs has the ability to create new ways of doing things, easily identify errors or problems in systems and recommend new solutions. They are watchful, alert and easily isolate business opportunities and think of original or improved products or serviced to take advantage of such opportunities.

Independence: Entrepreneurs are not content with situations where one's future and security are dependent upon forces outside one's control. They like to make own choices and set own pace i.e., freedom in bringing about changes and working towards challenging goals.

Risk: Entrepreneurs are not risk averse. They identify opportunities and take risks in exploiting those opportunities. They take calculated or moderate risk. They therefore set moderately difficult, but potentially achievable goals for themselves.

Zimmer and Scarborough (1996) outlined the risks that an entrepreneur may encounter as follows:

- Time risk: Time risk entails the time implication of taking a new idea through the product development phase until it could be considered right for the market.

- Investment risk: This includes the cost of establishment of a new venture, product development process, as well as those concerned with the physical manufacturing of the total product.

- Competitive risk: This is the risk associated with the possibility that competitors could be offering the same or comparable products in the market.

- Security risk: This is risk that relates with lives and properties of people in a state.

\subsection{Theoretical Framework}

This study is rooted on the dynamic innovation theory as was advocated by Schumpeter in 1949. The theory first considered entrepreneurship as the catalyst that disrupts the stationary circular flow of the economy and thereby initiates and sustains the process of development. According to him, entrepreneurship involves new combinations of the factors of production, which he succinctly termed innovation; indicating that the entrepreneur activates the economy to a new level of development. Schumpeter introduced a concept of innovations as key factor in entrepreneurship, in addition to assuming risk and organizing factors of production. He defines entrepreneurship as "creative activity" and described an innovator who brings new product or services into economy as an entrepreneur. The entrepreneur according to Schumpeter is viewed as the engine of growth- he sees the opportunity of introducing new products, new market and new sources of supply, new forms of industrial organization or for the development of newly discovered resources.

Schumpeter made a distinction between an innovator and an inventor. According to him, an inventor discovers new methods and new materials, on the contrary, an innovator is one who utilizes or applies inventions and discoveries in order to make new combinations. An innovator is concerned with his technical work of invention whereas an entrepreneur converts the technical work into economic performance.

\subsection{Review of Empirical literature}

Taiwo (2014) carried out an empirical research on impact of entrepreneurship development on job creation in Nigeria. He evaluated the relationship between job creation and entrepreneurship development in Nigeria. His findings show that in any given economy, entrepreneurship development always give birth to job creation which enable people to do something that will better their lives. It was however clear from his findings that job creation or employment opportunity in an economy can be traceable to entrepreneurship training and development. 
Akanwa and Akpanabia (2012) examined the need for promoting employment in Nigeria through the development of entrepreneurship. Findings from this study showed that entrepreneurship has much to do with employment creation. The study of Salami (2013) on youth unemployment in Nigeria established a link between entrepreneurship and youth unemployment. He found a positive relationship between unemployment and creativity and innovative intervention. Bandal (2010), conducted an empirical study on leveraging the relationship between entrepreneurship and job creation. His finding shows that individual talent, attitude, skills and knowledge along with several contextual variables such as social capital, access to credit, role of government technology and infrastructure, access to information and access to markets work together to drive entrepreneurial activities.

Ali and Ali (2013) study reveals that poverty indicators in a country will decrease with an increase in entrepreneurs because entrepreneurship creates new jobs, new markets, new technologies and new industries. In a related study by Baba (2013), it was confirmed that entrepreneurial skills drives economic development through job creation. Okoye, Iloanya and Udunze (2014), carried out a research on the extent to which entrepreneurship in Nigeria has helped to reduce youth unemployment. The study revealed that entrepreneurship is an engine for job creation, innovation and diversity.

As Leitch (2005) found that "entrepreneurial skills development represents particular ways of using capacities in relation to environmental demands with human being and external situations together forming a functional system" Ebiringa (2013) examined entrepreneurial skill development and growth of enterprises in Nigeria. He found out that several policy interventions in Nigeria aimed at stimulating entrepreneurship development through small and medium enterprises have failed. $\mathrm{He}$ proposed that government and the organized private sector should increase their support for entrepreneurial training programs as part of their contribution to the tertiary education system.

\section{Methodology}

This study adopted the survey design. It employed the questionnaire as instrument for data collection, designed in a five point likert scale of: strongly agree (5) to strongly disagree (1). The target population of the study consists of all Nigerian university graduates who established and run their own enterprises in the past ten years in Nigeria. To save cost and time, the researchers judgmentally divided the country into two zones: North and South.

The population of small enterprises which this target group fall into in these two zones is 9,122 and 12,142 respectively (Eluhaiwe, 2016). Kano representing North zone and Lagos representing South zone were selected to serve as focus areas for data collection, because they are the major commercial cities in the two zones under study. Population of graduate entrepreneurs operating for the past ten years in the (Kano) metropolis is given as 110 and that of the (Lagos) 156, which gave a total of 266. This population therefore formed the basis for calculating the sample size of this study.

To ensure good representative of the population, the sample size was determined using the TaroYamane Formula, given as: $\mathrm{n}=$

$$
1+\mathrm{N}(\mathrm{e})^{2}
$$

Where; $\mathrm{n}=$ sample size

$\mathrm{N}=$ Number of population

$\mathrm{e}=$ error margin which will be 0.05 (Ezirim, Briggs, Ebiringa, Akpobolokemi and Maclayton 2004).

Therefore the sample size; $\mathrm{n}=$

$$
\frac{266}{1+266(0.05)^{2}}
$$

$\mathrm{n}=160$

The Bowley's proportional formula was employed to select elements for each of the zones:

$$
\frac{\mathrm{nh}=\mathrm{n} \times \mathrm{Nh}}{\mathrm{N}}
$$

Where; $\mathrm{nh}=$ number of questionnaire that will be allocated to each zone.

$$
\mathrm{n}=\text { Total sample size }
$$


Efficacy of Entrepreneurial Skills Acquisition: A Study of Nigerian University Graduate Entrepreneurs in Kano and Lagos Metroplis

$\mathrm{Nh}=$ Number of entrepreneurs in the zones.

$\mathrm{N}=$ Population size (Kervin 1999)

To determine the sample size for Kano is thus;

$$
\mathrm{nh}=\frac{160 \times 156}{266}
$$

$\mathrm{nh}=94$

To determine the sample size for Lagos is thus;

$$
\begin{aligned}
& \text { nh }=\frac{160 \times 110}{266} \\
& \text { nh }=66
\end{aligned}
$$

Table1. Sample Size Determination

\begin{tabular}{|c|cc|cc|}
\hline Commercial Towns & \multicolumn{2}{|c|}{ Population of Entrepreneurs } & \multicolumn{2}{|c|}{ Sample size of Entrepreneurs } \\
\hline Kano & 156 & $59 \%$ & 94 & $59 \% \mathrm{xx}$ \\
\hline Lagos & 110 & $41 \%$ & 66 & $41 \% \mathrm{xx}$ \\
\hline TOTAL & 266 & $100 \%$ & 160 & $100 \%$ \\
\hline
\end{tabular}

Source: Survey Data, 2017.

Validity of the research instrument was established. The reliability of the instrument was conducted using the split half method. and its stability, accuracy or consistency was ascertained before use. Both the descriptive and inferential statistical tools were employed in this study. Descriptively, tables and percentages were used to group the responses of respondents to the questions that were asked, whereas, the Spearman's Rank correlation coefficient (r) statistical tool aided by SPSS was used in testing the formulated hypotheses.

\section{Data Presentation And Analysis}

Table2. As a university graduate did you acquire entrepreneurship skill in school to enable you create job for yourself?

\begin{tabular}{|c|l|l|l|l|l|}
\hline \multicolumn{2}{|c|}{ Scale } & Frequency & Percent & Valid Percent & Cumulative Percent \\
\hline \multirow{5}{*}{} & SD & 10 & 7.8 & 7.8 & 7.8 \\
\cline { 2 - 6 } & D & 14 & 10.9 & 10.9 & 18.8 \\
\cline { 2 - 6 } Valid & U & 1 & 0.8 & .8 & 19.5 \\
\cline { 2 - 6 } & A & 70 & 54.7 & 54.7 & 74.2 \\
\cline { 2 - 6 } & SA & 33 & 25.8 & 25.8 & 100.0 \\
\cline { 2 - 6 } & Total & 128 & 100.0 & 100.0 & \\
\hline
\end{tabular}

Source: Field Survey, 2017.

From the table 2 above, 10 respondents representing (7.8\%) strongly disagreed, 14 respondents $(10.9 \%)$ disagreed, 1 respondent representing $(0.8 \%)$ was undecided, while 70 respondents $(54.7 \%)$ agreed, and 33 respondents (25.8\%) strongly agreed on the subject matter.

Table3. Is there significant relationship between entrepreneurial skills acquisition and identification of business opportunities by Nigerian University graduates?

\begin{tabular}{|c|l|l|l|l|l|}
\hline \multicolumn{2}{|c|}{ Scale } & Frequency & Percent & Valid Percent & Cumulative Percent \\
\hline \multirow{5}{*}{ Valid } & SD & 9 & 7.0 & 7.0 & 7.0 \\
\cline { 2 - 7 } & D & 7 & 5.5 & 5.5 & 12.5 \\
\cline { 2 - 6 } & U & 4 & 3.1 & 3.1 & 15.6 \\
\cline { 2 - 6 } & A & 46 & 35.9 & 35.9 & 51.6 \\
\cline { 2 - 6 } & SA & 62 & 48.4 & 48.4 & 100.0 \\
\cline { 2 - 6 } & Total & 128 & 100.0 & 100.0 & \\
\hline
\end{tabular}

Source: Field Survey, 2017

From table 3 above, 9 respondents (7\%) strongly disagreed with the subject matter, 7 respondents (5.5\%) disagreed, 4 respondents $(3.1 \%)$ were undecided, 46 respondents $(35.9 \%)$ agreed and 62 respondents $(48.4 \%)$ strongly agreed. 
Efficacy of Entrepreneurial Skills Acquisition: A Study of Nigerian University Graduate Entrepreneurs in Kano and Lagos Metroplis

Table4. Is there significant relationship between entrepreneurial skills acquisition and the taking advantage of opportunities in business environment by Nigerian University graduates?

\begin{tabular}{|l|l|l|l|l|l|}
\hline \multicolumn{2}{|c|}{ Scale } & Frequency & Percent & Valid Percent & Cumulative Percent \\
\hline \multirow{5}{*}{ Valid } & SD & 12 & 9.4 & 9.4 & 9.4 \\
\cline { 2 - 6 } & D & 14 & 10.9 & 10.9 & 20.3 \\
\cline { 2 - 6 } & U & 2 & 1.6 & 1.6 & 21.9 \\
\cline { 2 - 6 } & A & 68 & 53.1 & 53.1 & 75.0 \\
\cline { 2 - 6 } & SA & 32 & 25.0 & 25.0 & 100.0 \\
\cline { 2 - 6 } & Total & 128 & 100.0 & 100.0 & \\
\hline
\end{tabular}

Source: Field Survey, 2017.

From table 4 above, 12 respondents $(9.4 \%)$ strongly disagreed with the subject matter, 14 respondents $(10.9 \%)$ disagreed, 2 respondents $(1.6 \%)$ were undecided, 68 respondents $(53.1 \%)$ agreed and 32 respondents $(25.0 \%)$ strongly agreed.

Table5. Is there significant relationship between entrepreneurial skills acquisition and the tendency to take calculated risk in business ventures by Nigerian University graduates?

\begin{tabular}{|l|l|l|l|l|l|}
\hline \multicolumn{2}{|c|}{ Scale } & Frequency & Percent & Valid Percent & Cumulative Percent \\
\hline \multirow{5}{*}{ Valid } & SD & 6 & 4.7 & 4.7 & 4.7 \\
\cline { 2 - 6 } & $\mathrm{D}$ & 16 & 12.5 & 12.5 & 17.2 \\
\cline { 2 - 6 } & $\mathrm{U}$ & 5 & 3.9 & 3.9 & 21.1 \\
\cline { 2 - 6 } & $\mathrm{A}$ & 52 & 40.6 & 40.6 & 61.7 \\
\cline { 2 - 6 } & SA & 49 & 38.3 & 38.3 & 100.0 \\
\cline { 2 - 6 } & Total & 128 & 100.0 & 100.0 & \\
\hline
\end{tabular}

Source: Field Survey, 2017

From table 5 above, 6 respondents (4.7\%) strongly disagreed, 16 respondents (12.5\%) disagreed, 5 respondents $(3.9 \%)$ undecided, while 52 respondents $(40.6 \%)$ agreed and 49 respondents $(38.3 \%)$ strongly agreed with the measured dimension.

\section{Hypothesis One}

Ho$_{1}$ : There no significant relationship between entrepreneurial skills acquisition and identification of business opportunities by Nigerian University graduates.

Table6. Correlations

\begin{tabular}{|c|c|c|c|c|}
\hline & & & \begin{tabular}{|lr} 
Use & of \\
entrepreneurial \\
skills r to \\
identify \\
business \\
opportunities \\
\end{tabular} & $\begin{array}{l}\text { Is there significant relationship } \\
\text { between entrepreneurial skills } \\
\text { acquisition and identification of } \\
\text { business opportunities by } \\
\text { Nigerian University graduates? }\end{array}$ \\
\hline \multirow{6}{*}{$\begin{array}{l}\text { Spearman's } \\
\text { rho }\end{array}$} & \multirow[t]{3}{*}{$\begin{array}{l}\text { Use of entrepreneurial skills to } \\
\text { identify business opportunities }\end{array}$} & $\begin{array}{l}\text { Correlation } \\
\text { Coefficient }\end{array}$ & 1.000 & $.894^{* *}$ \\
\hline & & Sig.(2tailed) & . & .000 \\
\hline & & $\mathrm{N}$ & 128 & 128 \\
\hline & \multirow{3}{*}{$\begin{array}{l}\text { Is there significant relationship } \\
\text { between entrepreneurial skills } \\
\text { acquisition and identification } \\
\text { of business opportunities by } \\
\text { Nigerian } \\
\text { graduates? }\end{array}$} & $\begin{array}{l}\text { Correlation } \\
\text { Coefficient }\end{array}$ & $.894^{* * *}$ & 1.000 \\
\hline & & Sig.(2tailed) & .000 & . \\
\hline & & $\mathrm{N}$ & 128 & 128 \\
\hline
\end{tabular}

**. Correlation is significant at the 0.01 level (2-tailed).

Table 6 shows the correlation between entrepreneurial skills and identification of business opportunities. The Spearman Rank correlation test shows a value of 0.894 (highlighted in boldface). Since the p-value (0.000) at 0.05 level of significance is less, the indication is that there is significant strong positive relationship between the measured dimensions (entrepreneurial skill acquisition and 
identification of business opportunities). Therefore we reject the null hypothesis and accept the alternative hypothesis.

\section{Hypothesis Two}

$\mathbf{H o}_{1}$ : There no significant relationship between entrepreneurial skills acquisition and taking advantage of business opportunities by Nigerian University graduates

Table7. Correlations

\begin{tabular}{|c|c|c|c|c|}
\hline & & & \begin{tabular}{|l} 
Use of \\
entrepreneurial skills \\
to take advantage of \\
business \\
opportunities.
\end{tabular} & $\begin{array}{l}\text { Relationship } \\
\text { entrepreneurial between } \\
\text { acquisition and the taking } \\
\text { advantage of business } \\
\text { opportunities }\end{array}$ \\
\hline \multirow{6}{*}{ Spearman's rho } & \multirow{3}{*}{$\begin{array}{l}\text { Use of entrepreneurial } \\
\text { skills to take advantage of } \\
\text { business opportunities. }\end{array}$} & $\begin{array}{l}\text { Correlation } \\
\text { Coefficient }\end{array}$ & 1.000 & $.991^{* *}$ \\
\hline & & Sig. (2-tailed) & . & .000 \\
\hline & & $\mathrm{N}$ & 128 & 128 \\
\hline & \multirow{3}{*}{$\begin{array}{l}\text { Relationship between } \\
\text { entrepreneurial } \\
\text { acquisition and the taking } \\
\text { advantage of business } \\
\text { opportunities. }\end{array}$} & $\begin{array}{l}\text { Correlation } \\
\text { Coefficient }\end{array}$ & $.991^{* *}$ & 1.000 \\
\hline & & Sig. (2-tailed) & .000 & . \\
\hline & & $\mathrm{N}$ & 128 & 128 \\
\hline
\end{tabular}

**. Correlation is significant at the 0.01 level (2-tailed)

Table 7 shows the correlation between entrepreneurial skills acquisition and taking advantage of business opportunities in the environment. The Spearman Rank correlation test shows a value of 0.991 (highlighted in boldface). Since the p-value (0.000) at 0.05 level of significance is less, the indication is that there is significant strong positive relationship between the measured dimensions (entrepreneurial skills acquisition and taking advantage of business opportunities in the environment). Therefore we reject the null hypothesis and accept the alternative hypothesis.

\section{Hypothesis Three}

$\mathbf{H}_{\text {O3: }}$ : There is no significant relationship between entrepreneurial skills acquisition and the tendency of Nigerian University graduates to take calculated risk in business ventures.

Table8. Correlations

\begin{tabular}{|c|c|c|c|c|}
\hline & & & $\begin{array}{l}\text { Use } \\
\text { entrepreneuri } \\
\text { al skills to } \\
\text { take } \\
\text { calculated } \\
\text { risk } \\
\end{array}$ & $\begin{array}{l}\text { Is there significant relationship } \\
\text { between entrepreneurial skills } \\
\text { acquisition and the tendency to } \\
\text { take calculated risk in business } \\
\text { ventures by Nigerian University } \\
\text { graduates? }\end{array}$ \\
\hline \multirow{6}{*}{$\begin{array}{l}\text { Spearman's } \\
\text { rho }\end{array}$} & \multirow{3}{*}{$\begin{array}{l}\text { Use of entrepreneurial skills to } \\
\text { take calculated risk }\end{array}$} & $\begin{array}{l}\text { Correlation } \\
\text { Coefficient }\end{array}$ & 1.000 & $.954^{* * *}$ \\
\hline & & \begin{tabular}{|l|} 
Sig.(2tailed) \\
\end{tabular} & . & .000 \\
\hline & & $\mathrm{N}$ & 128 & 128 \\
\hline & \multirow{3}{*}{$\begin{array}{l}\text { Is there significant relationship } \\
\text { between entrepreneurial skills } \\
\text { acquisition and the tendency to } \\
\text { take calculated risk in business } \\
\text { ventures by Nigerian University } \\
\text { graduates? }\end{array}$} & $\begin{array}{l}\text { Correlation } \\
\text { Coefficient }\end{array}$ & $.954^{\text {*** }}$ & 1.000 \\
\hline & & \begin{tabular}{|l|} 
Sig.(2tailed) \\
\end{tabular} & .000 & . \\
\hline & & $\mathrm{N}$ & 128 & 128 \\
\hline
\end{tabular}

**. Correlation is significant at the 0.01 level (2-tailed).

Table 8 shows the correlation between entrepreneurial skills acquisition and the tendency to take calculated risk in business ventures by Nigerian University graduates. The Spearman Rank correlation test shows a value of 0.954 (highlighted in boldface). Since the p-value $(0.000)$ at 0.05 level of significance is less, the indication is that there is significant strong positive relationship between the 
measured dimensions (entrepreneurial skills acquisition and the tendency to take calculated risk in business ventures). Therefore the null hypothesis is rejected and the alternative hypothesis upheld.

\section{DISCUSSION OF FINDINGS}

Upon the analysis of the responses and testing of the formulated hypothesis, the research confirmed the following:

In the test of hypothesis one, it was rejected while the alternative was accepted. This revealed that entrepreneurial skill acquisition helps Nigerian University graduates to identify business opportunities. This finding is in line with previous finding by Taiwo (2014) which reveals that job creation or employment opportunity in an economy can be traceable to entrepreneurship training and development, which means that entrepreneurial skill is the driving force behind self-employment and successful enterprise.

For the test of the second hypothesis, the null was rejected while the alternative was accepted. This implies that entrepreneurial skills acquisition helps Nigerian University graduates to take advantage of business opportunities in their environment. The result is in consonance with the findings of Leitch (2005) that says "entrepreneurial skills development represents particular ways of using capacities in relation to environmental demands with human being and external situations together forming a functional system".

In the test of the third hypothesis, the null was refuted while the alternative was upheld. This reveals that there is significant relationship between entrepreneurial skills acquisition and the tendency to take calculated risk in business ventures. This finding agrees with Zimmer and Scarborough (1996) who found that the successful entrepreneur is one who capitalizes on the constructive effect of the conflict situation that originates when a certain risk is taken.

\section{CONCLuSion}

Based on the result of our findings, conclusion is drawn that:

Entrepreneurial skills acquisition helps Nigerian university graduates to identify and utilize business opportunities in their environment. In addition, risk taking is strongly linked with entrepreneurial skills in every business venture. To crown it all, entrepreneurial skills equip university graduates to create ventures for themselves and contribute to economic growth.

\section{RECOMMENDATIONS}

It is proposed that the entrepreneurship programme organized by Nigerian Universities should be repositioned to focus more on entrepreneurial skills acquisition which equips students for venture creation and self employment. This is for the fact that the economic development of every nation hinges on her ability to equip youths who are well prepared to take initiatives and innovate. Finally, measures should be put in place to ensure that policy framework relating to entrepreneurship programme is galvanized, properly implemented and sustained.

\section{REFERENCES}

[1] Adeyemo, S.A (2009). Studies of the effects of aptitude, instructional leadership styles and learning: Environment on student's achievement in physics. Doctoral thesis: University of Lagos, Nigeria.

[2] Akanwa, P. U. and Akpanabia, N. H. (2012). Entrepreneurship Development as Panacea for Unemployment Reduction in Nigeria: Reikojournals.org.

[3] Ali D. A and Ali, A.Y (2013) Entrepreneurship Development and poverty Reduction: Empirical Survey from Somalia, American International Journal of Social Sciences 2: 108-113

[4] Amaechi, U. F. (2005). Entrepreneurship, Enugu: Hybrid Publishers

[5] Anyadike, N. Emeh, I. \& Ukah, F. O. (2012). Entrepreneurship Development and Employment generation in Nigeria: Problems and Prospects. Available in http:/www.universalresearchjournals.org/ujegs retrieved on $4^{\text {th }}$ April 2016.

[6] Bagheri A and Pihie Z.A (2010) Entrepreneurial Leadership Learning: In Search of Missing Links, Procedia-Social and Behavioural Sciences 7: 470-479

[7] Bandal, S. (2010). Entrepreneurship and Job Creation: Leveraging the Relationship. New York: American Management Association. 
[8] Baron A and Henry R (2010) How Entrepreneurs Acquire the Capacity to Excel: Insights from Research on Expert Performance, Strategic Entrepreneurship Journal, 4 (1), 49-65.

[9] Bosiak, D. (2013). Leadership Styles and Creativity. Available in http://www.iiakm.org/ojakm/articles/ 2013/volume1-2 /ojakmvolume1-2 pp64-77 retrieved on 24th April 2016

[10] Ebiringa, O. T. (2013). Perspective: Entrepreneurship Development and Growth of Enterprises in Nigeria. Onitsha: Good Success Press.

[11] Eluhaiwe , P. N., (2016) How Micro Small and Medium Enterprises (MSMEs) Can Leverage on Central Bank of Nigeria's Real Sector Initiatives, Bullion; Publication of the Central Bank of Nigeria, Volume 40, No. 2, April - June.

[12] Esomonu, B. N. (1998). The State of Entrepreneurship Education in Nigeri; Lagos, Longman Nigeria.

[13] Ezirim, A. Briggs, B. R., Ebiringa, O. T. Akpobolokemi. P. Z. \& Maclayton, D. W. (2004). Research Methodology for Management and Social Sciences; Anambra: MC Computer Press.

[14] Fills, I. (2012).The Role of Creativity in Entrepreneurship. Available in http://snap.3.lias.mx/Recurso/ libroselectronics. Retrieved on 18th March 2016.

[15] Kervin, J. B. (1999). Methods for Business Research: (2 ${ }^{\text {nd }}$ edition). New York: Harper Collins.

[16] Khanka, S. S. (2002). Entrepreneurship Development: New Delhi: Chand and Company Ltd.

[17] Kilby, P. (1971). Hunting the Heffalump in P KILBY ed. Entrepreneurship and Economic Development. New York: The Free Press.

[18] Kueaiko D and Hodges (2004) Entrepreneurship Theory, Process, Practice, $6^{\text {th }}$ Edition, Stanford, C.I, Thomas South Western.

[19] Leitch, L. (2005). The Long Term Challenge: Review of Skills in the UK; Interim Report, London.

[20] Martin R and Osberg S (200), Social Entrepreneurship: The Case for Definition; Stanford Social Innovation Review: www.ssireview.org

[21] Okoye, N. C., Iloanya, K. \& Udunze, U.(2014). Youth unemployment and Entrepreneurship Development: Challenges and Prospects in Nigeria. Kuwait chapter of Arabian; Journal of Business and Management Review.

[22] Onyeaghala, O.H. Edema, A. J. M. \& Orji, C. O. (2013) Vocational Skills Acquisition and Job Creation in Nigeria.FUW- International journal of Management and Social Sciences, vol.1.

[23] Ottih, L.O. (2000). Entrepreneuring towards Preparedness; Port Harcourt: Pearl Publishers

[24] Owualah, S. I. (1999). Entrepreneurship in Small Business Firms: Lagos: GMAG Investment Ltd.

[25] Pleshetter, L. A. (2009). Must have skills for Entrepreneurs: available at http:www.powerhomebiz.com /vol69/entreskills.htm. Retrieved on $1^{\text {st }}$ June 2016.

[26] Rae, D. (2007). Entrepreneurship: from Opportunity to Action. New York: Palgrave, Macmillan.

[27] Schumpeter, J. A. in: Stevenson (2007). The theory of Economic Development: Cambridge, MA: Harvard University Press.

[28] Sule, E .L .K. (1986). Small Scale Industries in Nigeria: Concepts and Appraisal of Governemnt Policies and Suggested Solutions to Identified Problems; Journal of Economic and Financial Review. 24(4).

[29] Taiwo, O.E. (2014). Impact of Entrepreneurship Development on Job Creation in Nigeria: Journal of Department of Business Administration, University of Illorin Nigeria.

[30] The National Directorate of Employment (1989); Annual Newsletter

[31] Tijani, A.B. (2004). Entrepreneurship Processes and Small Business Management, Enugu: RhyceKerex Publishers.

[32] Uru, F.O. and Yozgat, U. (2009). Creativity for Gaining Competitive Advantage: the role of leadership style. Available in http://isma.infoluploads/files/creativity-forgainingandsustaining-competitive-advantagethe-role-of-leadership-styles-pdf. Retrieved on $22^{\text {nd }}$ May,2016.

[33] Zimmerer, T.W.and Scarborough, N.M. (1996). Entrepreneurship and New Venture Formation: New Jersey: Prentice Hall.

\section{AUTHORS' BIOGRAPHY}

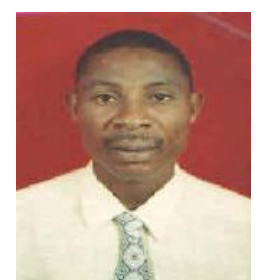

Dr. Onyeaghala Obioma Hyginus is a product of University of Calabar and Ebonyi State University Abakaliki, Nigeria. As a distinguished scholar, he was a recipient of best Conference paper award: International Institute of Engineers and Researchers, Dubai in 2015. He has published extensively in reputable scholarly Journals. Obioma is a Senior Lecturer and Acting Head, Department of Business Administration, Federal University Wukari. 
Efficacy of Entrepreneurial Skills Acquisition: A Study of Nigerian University Graduate Entrepreneurs in Kano and Lagos Metroplis

Okorie Goodluck, graduated from Federal University Wukari. He studied Business Administration.

Citation: Onyeaghala Obioma H., \& Okorie Goodluck. " Efficacy of Entrepreneurial Skills Acquisition: A Study of Nigerian University Graduate Entrepreneurs in Kano and Lagos Metroplis" International Journal of Managerial Studies and Research (IJMSR), vol 6, no. 5, 2018, pp. 9-20. doi:http://dx.doi.org/10.20431/2349. 0349.0605002.

Copyright: () 2018 Authors. This is an open-access article distributed under the terms of the Creative Commons Attribution License, which permits unrestricted use, distribution, and reproduction in any medium, provided the original author and source are credited. 